\title{
KONSTRUKSI KONSEP MENJANJIKAN SEBAGAIMANA DI MAKSUD PADA PASAL 5 AYAT (1) HURUF A UU NO. 20 TAHUN 2001
}

\author{
Daky Dzul Qornain \\ Polres Bojonegoro \\ Email : daki1994@gmail.com
}

\begin{abstract}
Abstrak
Syarat yang harus ada dalam suatu perbuatan agar dapat dipidana diawali bahwa perbuatan itu melawan hukum, yang sudah melalui proses sebagaimana diatur dalam peraturan perundang-undangan. Istilah menjanjikan yang terdapat dalam rumusan Pasal 5 ayat (1) huruf a UU No. 20 Tahun 2001 tentang Tindak Pidana Korupsi, tidak sama pengertiannya dengan yang terdapat dalam Kamus Besar Bahasa Indonesia. Perbuatan "menjanjikan" dalam UU No. 20 Tahun 2001 dilakukan oleh pihak yang memiliki kepentingan atau yang memiliki tujuan pada pegawai negeri atau penyelenggara negara.
\end{abstract}

Kata kunci: korupsi, konsep menjanjikan, kerugian

\begin{abstract}
The conditions that must exist in an act in order to be convicted are preceded by the fact that the act is against the law, which has gone through the process as regulated in statutory regulations. Promising terms contained in the formulation of Article 5 paragraph (1) letter a of Law no. 20 of 2001 concerning Corruption Crime, the meaning is not the same as that contained in the Big Indonesian Dictionary. Actions "promising" in Law no. 20 of 2001 carried out by parties who have an interest in or have goals in civil servants or state officials.
\end{abstract}

Keywords: corruption, promising concept, loss

\section{PENDAHULUAN}

Secara alamiah setiap individu dibekali oleh dua sifat yang universal, yaitu sifat kelebihan dan pada sisi yang bersamaan setiap individu juga memiliki sifat kelemahan. Sisi kelebihan yang dimiliki oleh setiap individu cenderung digunakan untuk berbuat baik, dan bahkan menyebar kebaikan di antara individu-individu yang lain atau komunitasnya. Individu yang mengedepankan sisi kelebihannya, ia selalu berkeinginan untuk menjadi individu yang baik. Bagi individu yang mengedepankan sisi kelebihannya, maka ia selalu berhati-hati dalam berbuat atau bertindak. Karena individu yang demikian, dalam berbuat atau bertinda senantiasa menggunakan hati nuraninya di samping pikiran yang rasional.

Sedangkan sisi kelemahan yang di miliki oleh setiap individu terbuka ruang untuk melakukan sebaliknya dengan sisi kelebihan yang dimiliki oleh setiap individu. Dalam artian individu yang mengedepankan sisi kelemahannya, biasanya ia selalu berfikir negatif sampai-sampai tindakan atau perbuatannya cenderung melanggar peraturan perundang-undangan. Tipikal individu yang demikian, karena faktor mendahulukan kepentingan individunya dibandingkan 


\section{Jurnal Negara dan $\mathcal{X}$ eadilan \\ p-ISSN 2302-7010 e-ISSN 2721-9801}

kepentingan yang lebih luas. Lebih-lebih kepentingan individu tersebut cenderung tidak dilandasi oleh pola pikir yang rasional. Akibat dari tindakan atau perbuatan yang mementingkan pribadi dan tidak dilandasi pikiran yang rasional itulah, individu yang demikian dalam berbuat dan melakukan tindakan ruang atau potensi untuk merugikan pihak lain sangat terbuka. Sehingga yang membedakan kedua sisi yang di miliki setiap individu antara nilai kelebihan dan sisi kelemahan tersebut terletak pada dampak atau akibat yang muncul dari perbuatan atau tindakan dari masing-masing individu.

Ketika individu itu melaksanakan sisi kelebihannya, maka individuindividu dan kelompok dari individu-individu itu merasakan nilai manfaat. Karena perbuatan atau tindakan tersebut cenderung membawa nilai positif, apalagi perbuatan atau tindakan tersebut secara normatif tidak melanggar peraturan perundang-undangan yang berlaku. Tetapi ketika individu itu menunjukkan sisi kelemahannya, maka cenderung melahirkan nilai negatif, dan cenderung merugikan baik secara individu maupun beberapa orang dan kelompoknya, dan bahkan tindakannya itu melanggar peraturan perundang-undangan yang berlaku. Dalam kenyataannya, ketika individu itu sudah didominasi oleh faktor kelemahan yang dimilikinya, karena itu lebih dekat pada sisi kekurangannya, ia melakukan suatu perbuatan atau tindakan yang justeru melanggar peraturan perundangundangan yang berlaku. Dengan kata lain, salah satu bentuk yang cenderung dilakukan oleh individu-individu yang di dominasi oleh sisi kekurangannga adalah ia melakukan perbuatan melanggar hukum atau melawan hukum.

Karena secara alamiah siapa saja memiliki potensi untuk melakukan perbuatan yang dikatagorikan perbuatan melawan hukum, katagori tersebut juga dapat menimpa masyarakat, pegawai negeri sipil dan penyelenggara negara atau pemerintahan. Perbuatan melawan hukum bagi pegawai negeri sipil atau ASN dan penyeleggara negara atau pemerintahan biasanya dilakukan bila ia memiliki kewenangan dalam jabatannya. Bentuk perbuatan melawan hukum itu biasanya dilakukan melalui keputusan-keputusan yang dikeluarkannya baik keputusan tertulis maupun keputusan secara lisan. Bentuk perbuatan yang dikatagorikan sebagai perbuatan melawan hukum itu biasanya bervariasi bergantung pada perspektif, diantaranya adalah perbuatan tindak pidana korusip. Dalam perspektif hukum, definisi korupsi secara gamblang telah dijelaskan dalam 13 buah Pasal dalam UU No. 31 Tahun 1999 yang telah diubah dengan UU No. 20 Tahun 2001 tentang Pemberantasan Tindak Pidana Korupsi. Penggolongan kejahatan tindak pidana korupsi yang berlaku di Indonesia relatif banyak. Berdasarkan pasal-pasal tersebut di atas, korupsi dirumuskan kedalam 30 bentuk/jenis tindak pidana korupsi. Pasal-pasal tersebut menerangkan secara terperinci mengenai perbuatan yang bisa dikenakan sanksi pidana karena korupsi. Ketigapuluh bentuk/jenis tindak pidana korupsi tersebut pada dasarnya dapat dikelompokkan sebagai berikut: ${ }^{1}$

1. Kerugian keuangan negara;

2. Suap-menyuap;

3. Penggelapan dalam jabatan;

${ }^{1}$ M. Syamsa Ardisasmita, DEA, Definisi Korupsi Dalam Perspektif Hukum Dan EAnnouncement Untuk Tata Pemerintahan Yang Lebih Terbuka Transparan dan Akuntabel, Makalah Seminar Nasional Upaya Perbaikan Sistem Penyelenggaraan Pengadaan Barang/ Jasa Pemerintah, Jakarta: 2006. hal. 4. 


\section{Zurnal Negara dan $\mathcal{X}$ eadilan \\ p-ISSN 2302-7010 e-ISSN 2721-9801}

4. Pemerasan;

5. Perbuatan curang;

6. Benturan kepentingan dalam pengadaan;

7. Gratifikasi.

Selain bentuk/jenis tindak pidana korupsi yang sudah dijelaskan diatas, masih ada tindak pidana lain yang yang berkaitan dengan tindak pidana korupsi yang tertuang dalam UU No.31 Tahun 1999 Jonto UU No. 20 Tahun 2001. Jenis tindak pidana yang berkaitan dengan tindak pidana korupsi itu adalah:

1. Merintangi proses pemeriksaan perkara korupsi;

2. Tidak memberi keterangan atau memberi keterangan yang tidak benar;

3. Bank yang tidak memberikan keterangan rekening tersangka;

4. Saksi atau ahli yang tidak memberi keterangan atau memberi keterangan palsu;

5. Orang yang memegang rahasia jabatan tidak memberikan keterangan atau memberikan keterangan palsu;

6. Saksi yang membuka identitas pelapor.

\section{METODE PENLITIAN}

Jenis penelitian yang digunakan dalam penulisan tesis ini menggunakan jenis penelitian normatif. Penelitian normatif adalah penelitian hukum yang mencakup penelitian terhadap asas-asas hukum, penelitian terhadap sistematika hukum, penelitian terhadap taraf sinkhronisasi hukum, penelitian sejarah hukum, dan penelitian perbandingan hukum. ${ }^{2}$ Pendekatan penelitian yang digunakan dalam penulisan tesis ini menggunakan jenis pendekatan:

a. Pendekatan Perundang-undangan (Statute Approach). ${ }^{3}$

b. Pendekatan konseptual (Conceptual Approach),. ${ }^{4}$

Teknik analisis bahan hukum yang digunakan dalam penulisan tesis ini adalah metode analisis deskriptif terhadap sistematika hukum. Kerangka acuan yang dipergunakan adalah kesesuaian dengan permasalahan yang dikaji dalam penulisan tesisi ini. Metode yang digunakan adalah metode berpikir deduktif, yaitu metode berpikir yang penarikan kesimpulannya ditarik dari sesuatu yang bersifat umum yang sudah dibuktikan dengan benar dan kemudian kesimpulannya dijabarkan secara khusus.

\section{PEMBAHASAN}

Rincian sebagaimana dimaksud di atas, pada dasarnya dapat dilakukan oleh semua subyek hukum terutamanya penyelenggara negara atau pemerintahan. Perbuatan yang dikatagorikan sebagai perbuatan melawan hukum bagi penyelenggara negara atau pemerintahan, pegawai negeri sipi atau ASN salah satunya sesuai dengan yang dikaji dalam proposal ini adalah tiindak pidana korupsi, dimana perbuatan tersebut berupa menjanjikan atau dijanjikan untuk diberi sesuatu hal yang dilakukan oleh orang lain karena ia sebagai penyelenggara

\footnotetext{
${ }^{2}$ Soerjono Soekanto, Pengantar Penelitian Hukum, (Jakarta, UI Press: 1981), hlm. 51.

${ }^{3}$ Peter Mahmud Marzuki, Penelitian Hukum, (Jakarta, Prenada Media Group, 2010),

${ }^{4}$ Ibid, hlm. 166.
} hlm.137. 


\section{$\mathcal{H}$ urnal Negara dan Keadilan \\ p-ISSN 2302-7010 e-ISSN 2721-9801}

negara atau pemerintahan atau karena ia sebagai aparatur negara atau pemerintahan. Bentuk perbuatan tersebut dalam peraturan perundang-undangan dikatagorikan sebagai perbuatan melawan hukum di bidang tindak pidana korupsi. Berdasarkan ketentuan Pasal 5 ayat (1) Undang-Undang Nomor 20 Tahun 2001 perubahan dari Undang-Undang Nomor 31 Tahun 1999 tentang Pemberantasan Tindak Pidana Korupsi. Pasal 5 ayat (1) menyatakan: dipidana dengan pidana penjara paling singkat 1 (satu) tahun dan paling lama 5 (lima) tahun dan/atau pidana denda paling sedikit Rp. 50.000.000,- (lima puluh juga rupiah) dan paling banyak Rp. 250.000.000,- (dua ratus lima puluh ribu rupiah) setiap orang yang:

a. Memberi atau menjanjikan sesuatu pada pegawai negeri atau penyelenggara negara dengan maksud supaya pegawai negeri atau penyelenggara negara tersebut berbuat atau tidak berbuat sesuatu dalam jabatannya yang bertentangan dengan kewajibannya; atau

b. Memberi sesuatu kepada pegawai negeri atau penyelenggara negara karena atau berhubungan dengan sesuatu yang bertentangan dengan kewajiban, dilakukan atau tidak dilakukan dalam jabatannya.

Rumusan ketentuan Pasal 5 ayat (1) sebagaimana disebutkan diatas, belum menunjukkan adanya perbuatan atau tindakan konkret dari setiap orang. Tetapi setiap orang tersebut yang dimaksud dalam ketentuan Pasal 5 ayat (1) hanya sebatas menjanjikan sesuatu hal kepada penyelenggara negara atau pemerintahan. Namun demikian janji yang diperjanjiakan oleh setiap orang tersebut memiliki karakteristik yang dapat mempengaruhi diri pegawai negeri sipil untuk melakukan sesuatu atau tidak melakukan sesutu karena jabatan yang di embannya.

Berdasarkan ulasan tersebut di atas, tampak bahwa percobaan untuk menyerahkan sesuatu karena diawali dengan menjanjikan sesuatu kepada penyelenggaran negara atau pemerintahan masuk katagori perbuatan korupsi. Padahal secara konkret unsur merugikan negaranya belum terjadi. Politik hukum melalui pasal-pasal dalam UU No. 20 Tahun 2001 terutama Pasal 5 ayat (1) yang mana faktor atau unsur kerugian negaranya belum terjadi juga dikatagorikan sebagai bagian dari tindak pidana korupsi secara prinsipil juga tidak dapat disalahkan. Karena sepertinya pembentuk UU merumuskan pasal-pasal tersebut sebagai bagian bentuk preventif agar semua penyelenggara negara atau pemerintahan fokus pada tanggung jawabnya sebagai abdi negara secara profesional.

Kata menjanjikan sebagaimana diatur dalam ketentuan Pasal 5 ayat (1) UU No. 20 Tahun 2001 itu tidak terpisahkan dari jabatan sebagai pegawai negeri sipil atau penyelenggara negara atau pemerintahan. Karena seseorang tidaklah mungkin menjanjikan sesuatu kepada penyelenggara negara atau pemerintahan tanpa memiliki maksud tersembunyi dari tindakan menjanjikan tersebut. Sikap penyelenggaran negara atau pemerintahan dalam rumusan Pasal 5 ayat (1) UU No. 20 Tahun 2001 tidak sebatas ia sebagai penyelenggara mengeluarkan keputusan secar surat, tetapi rumusan ketentuan tersebut juga menjerat setiap penyelenggaran negara atau pemerintahan yang diam, padahal seharusnya ia melakukan sesuatu. Jadi diamnya dari penyelenggara negara atau pemerintahan yang secara hukum dapat dibuktikan karena telah menerima janji sesuatu dari orang, maka diamnya tersebut bagian dari tindak pidana korupsi.

Keberlakuan UU No. 20 Tahun 2001 memang bagian dari tujuan negara di bidang hukum dan kesejahteraan sosial. Bersadarkan konsideran UU No. 20 


\section{Hurnal Negara dan $\mathcal{X}$ eadilan \\ p-ISSN 2302-7010 e-ISSN 2721-9801}

Tahun 2001 menyatakan: tindak pidana korupsi yang selama ini terjadi secara meluas, tidak hanya merugikan keuangan negara, tetapi juga telah merupakan pelanggaran terhadap hak-hak sosial dan ekonomi masyarakat secara luas, sehingga tindak pidana korupsi perlu digolongkan sebagai kejahatan yang pemberantasannya harus dilakukan secara luar biasa. Namun demikian, penanganan luar biasa dalam pemberantasan tindak pidana korupsi ini bukan berarti apparat penegak hukum dalam melakukan tindakan secara sewenangwenang. Dalam artian prinsip kehati-hatian tetap menjadi bagian yang harus di jadikan sebagai ukuran, agar model penanganan tersebut tidak melanggar hak-hak penyelenggara negara atau pemerintahan itu sendiri.

Oleh karena itu, sifat hukum yang tidak memihak atau equal harus dipandang dan nilai sebagai prinsip utama dalam penegakan hukum terutama di bidang tindak pidana korupsi. Salah satu cara yang penulis nilai benar adalah penegak hukum harus memiliki kemampuan menterjemahkan makna dari rumusan norma yang ada dalam setiap peraturan perundang-undangan khususnya yang terkait langsung dengan norma mengenai tindak pidana korupsi. Sehingga proses penegakan hukum tindak pidana korupsi itu benar-benar dilakukan secara tepat dan profesional. Dalam situasi demikian sumber daya manusia bagi penegak hukum menjadi salah satu modal utama, karena sumber daya manusia bagian yang tidak terpisahkan dengan kemampuan para penegak hukum dalam kecakapannya melakukan interpretasi atau penafsiran dan memahami makna dalam sebuah norma.

Perbuatan melawan hukum yang berbentuk tindak pidana korupsi merupakan perbuatan yang memiliki akses luas dibandingkan tindak pidana lainnya. Tindak pidana korupsi memiliki kemiripan dengan tindak pidana terorisme yang keduanya memiliki dampak atau akibat tidak hanya berpotensi merugikan satu atau beberapa orang saja, melainkan kerugian yang ditimbulkan oleh perbuatan tindak pidana korupsi dapat merugikan bangsa dan negara. Menurut pendapat Baharuddin Lopa, tindak pidana korupsi merupakan suatu sifat tercela dan sudah menjadi fenomena sosial yang tidak hanya merugikan negara tetapi juga merupakan suatu pelanggaran hak-hak sosial dan ekonomi masyarakat. Hal ini dapat dimaklumi mengingat dampak negatif yang ditimbulkan oleh korupsi. Korupsi merupakan kejahatan sistemik yang berkaitan dengan kekuasaan yang terbentuk secara struktural dan terorganisir. Korupsi dapat merusak sendisendi kepribadian bangsa terutama yang diakibatkan oleh intellectual corruption. ${ }^{5}$

Ketentuan Pasal 5 ayat (1) UU No. 20 Tahun 2001 merupakan norma dimana seseorang hanya menjanjikan sesuatu kepada pegawai negeri sipil karena jabatannya, baik ia melakukan tindakan atau perbuatan tertentu maupun ia diam. Tetapi memang untuk mengatakan adanya hubungan causalitas antara yang dijanjikan itu dengan diamnya seorang pegawai sipil memerlukan pembuktian yang relatif tidak mudah untuk dilakukan. Di samping itu konsep menjanjikan dan batasan kewajiban bertindak dalam jabatan yang bagaimana yang mengakibatkan seorang pegawai negeri sipil itu dapat di jerat dengan ketentuan Pasal 5 ayat (1) UU No. 20 Tahun 2001.

Indonesia adalah negara hukum sebagaimana diatur dalam ketentuan Pasal 1 ayat (3) Undang-Undang Dasar Negara Tahun 1945. Dalam konteks negara

\footnotetext{
${ }^{5}$ Baharuddin Lopa, Kejahatan Korupsi dan Penegakan Hukum, Cetakan Pertama, (Jakarta: Kompas, 2000), hlm. 74.
} 


\section{$\mathcal{H}$ urnal Negara dan Keadilan \\ p-ISSN 2302-7010 e-ISSN 2721-9801}

hukum semua perbuatan dan tindakan yang dilakukan oleh semua subyek hukum (baik itu sebagai penguasa maupun sebagai warga negara) harus didasarkan pada hukum yang berlaku. Hukum yang berlaku, tidak selalu berlaku efektif, dan tidak selalu mendapat apresiasi dari setiap individu atau warga negara, dan bahkan hukum yang berlaku dikritisi oleh individu sebagai warga negara. Tidak hanya itu saja, hukum yang berlaku bisa saja rumusan norma yang dituangkan dalam hukum itu kurang tepat bahkan salah. Oleh karena itu, muatan materi yang dijadikan sebagai norma dalam hukum itu harus memenuhi syarat-syarat formil dan materiil, termasuk mengacu pada peraturan perundang-undangan yang berlaku.

Sebagaimana bentuk negara hukum, maka negara harus mampu mengatur berbagai kebutuhan masyarakat melalui produk-produk hukumnya yang memang secara faktual bagian dari kebutuhan masyarakat. Karena tanpa didasari kebutuhan masyarakat secara konkret, maka produk hukum yang dibentuk oleh negara tidak akan dapat berjalan secara normal. Padahal hukum hanya dibutuhkan untuk mengatur manusia. Negara hukum Indonesia tentunya memiliki karakter yang tidak sama dengan negara hukum negara-negara lain dunia. Meskipun klasifikasi hukumnya sama. Misalnya hukum perdata, hukum administrasi negara, hukum pidana dan lain sebagainya.

Hukum pidana merupakan hukum yang mengatur hubungan hukum antara negara dengan warga negaranya. Jadi dalam diri hukum pidana itu melibatkan negara atau kekuasaan. Dalam kajian hukum pidana itu sendiri para ahli hukum mengklasifikasi antara hukum pidana matriil dan hukum pidana formil. Hukum pidana meteriil terdiri atas tindak pidana yang disebut berturut-turut, peraturan umum yang dapat diterapkan teerhadap Penyesuaian baik secara formil dan materiil disetiap pembentukan peraturan perundang-undangan setidaknya dapat mengurangi terjadinya cacat dalam sudut pandang hukum. Apalagi rumusan sebuah peraturan itu mengenai aspek pidana khsusnya dibidang kejahatan tindak pidana korupsi. Karena pada dasarnya kejahatan tindak pidana korupsi berkaitan langsung dengan kesejahteraan dan perlindungan hak-hak warga negara. Pemikiran tersebut berangkat dari pemikiran, bahwa kejahatan tindak pidana korupsi yang dilakukan baik secara individu, kelompok maupun oleh badan hukum merupakan tindakan kejahatan sistematis yang mengambil hak-hak warga negara yang prinsipil warga negara itu sebagai pemilik harta yang telah di korupsi. Kejahatan tindak pidana korupsi bahkan dikatagorikan sebagai kejahatan yang merampas hak asasi manusia. Oleh karena itu, kejahatan korupsi dimaknai sebagai tindakan jahat yang pengertiannya luas.

Kejahatan tindak pidana korupsi tidak hanya memiliki dampak negatif kepada pihak yang melakukan korupsi dan keluarganya, melainkan juga dapat mempengaruhi eksistensi negara. Karena ketika kejahatan tindak pidana korupsi itu dilakukan secara terus menerus yang sifatnya masif, terstruktur dan sistematis, maka pelan-pelan negara akan mengalami kebangkrutan. Saat negara mengalami kebangkrutan itulah eksistensi negara mulai dipertanyakan karena negara tidak mungkin lagi dapat menjalankan fungsi-fungsi pokoknya sebagaimana diatur dalam konstitusi.

Dalam konsideran Undang-Undang Nomor 20 Tahun 2001 (selanjutnya disebut UU No. 20 Tahun 2001) dinyatakan: bahwa tindak pidana korupsi yang selama ini terjadi secara meluas tidak hanya merugikan keuangan negara, tetapi juga telah merupakan pelanggaran terhadap hak-hak sosial dan ekonomi 


\section{Hurnal Negara dan $\mathcal{X}$ eadilan \\ p-ISSN 2302-7010 e-ISSN 2721-9801}

masyarakat secara luas, sehingga tindak pidana korupsi perlu digolongkan sebagai kejahatan yang pemberantasannya harus dilakukan secara luar biasa. Sedangkan pengertian korupsi itu sendiri baik dalam UU No. 31 Tahun 1999 maupun UU No. 20 Tahun 2001 perubahan atas UU No. 31 Tahun 1999 tentang Pemberantasan Tindak Pidana Korupsi tidak mengatur pengertian korupsi secara jelas.

Berdasarkan uraian tersebut di atas, maka cukup rasional manakala kejahatan tindak pidana korupsi yang berlaku diartikan secara luas yang tersebar dalam peraturan perundang-undangan yang berlaku. Oleh karena itu, kejahatan korupsi tidak hanya melingkupi sebuah tindakan nyata yang merugikan keuangan negara. Melainkan pengertian tindak pidana korupsi juga melingkupi niat dan rencana yang mana tindakan itu belum dilakukan. Seorang pegawai negeri yang mendapat janji dari pihak lain untuk melakukan atau tidak melakukan sesuatu yang pada dasarnya melampaui kewajibannya, maka pegawai negeri itu dikatagorikan bagian dari melakukan tindak pidana korupsi.

Kejahatan tindak pidana korupsi yang secara teoritik termasuk bagian tindak pidana khusus, dalam merumuskan deliknya tidak sama dengan perumusan pidana umum. Karena ciri khas dalam tindak kejahatan korupsi itu adalah mengenai keuangan negara. Menurut hemat penulis keuangan negara yang dimaksud dalam kejahatan tindak pidana korupsi adalah keuangan negara dalam arti yang luas. Misalnya lembaga-lembaga swasta yang pengopearsionalannya menggunakan uang negara apabila terdapat pelanggaran hukum sebagai yang daitur dalam UU No, 30 Tahun 1999 Jonto UU No. 20 Tahun 2001 juga bagian dari kejahatan tindak pidana korupsi.

Syarat yang harus ada dalam suatu perbuatan agar dapat dipidana diawali bahwa perbuatan itu melawan hukum, yang sudah melalui proses sebagaimana diatur dalam peraturan perundang-undangan. Istilah menjanjikan yang terdapat dalam rumusan Pasal 5 ayat (1) huruf a UU No. 20 Tahun 2001 tentang Tindak Pidana Korupsi, tidak sama pengertiannya dengan yang terdapat dalam Kamus Besar Bahasa Indonesia. Perbuatan "menjanjikan" dalam UU No. 20 Tahun 2001 dilakukan oleh pihak yang memiliki kepentingan atau yang memiliki tujuan pada pegawai negeri atau penyelenggara negara sebagaimana dimasud dalam Pasal 5 ayat (1) hurif a UU No. 20 Tahun 2001. Sedangkan istilah "menjanjikan" dalam Kamus Besar Bahasa Indonesia itu dilakukan oleh pegawai negeri atau penyelenggara negara. Dalam pengertian perbuatan menjanjikan dalam UU No. 20 Tahun 2001 berawal dari pihak yang berkepentingan, sedangkan perbuatan "menjanjikan" dalam Kamus Besar Bahasa Indonesia bersumber dari pegawai negeri. Perbuatan menjanjikan yang terdapat dalam Pasal 5 ayat (1) huruf a bagian dari makna korupsi secara luas, di samping tindak pidana korupsi itu merupakan kejahatan kemanusiaan dan juga dikatagorikan sebagai bentuk kejahatan luar biasa atau extra ordinary crimes.

\section{PENUTUP}

Undang-Undang Nomor 30 Tahun 1999 Jonto UU No. 20 Tahun 2001 tentang Pemberantasan Tindak Pidana Korupsi tidak mengatur batasan-batasan kewajiban yang harus dipenuhi dalam pekerjaannya sebagai pegawai negeri atau penyelenggara negara kecuali kewenangan yang dimiliki. Oleh karena itu, dengan tidak adanya batasan-batasan kewajiban dalam melaksanakan pekerjaannya bagi pegawai negeri, terdapat dua pandangan yang berbeda. Pertama, terkait durasi 


\section{Jurnal Negara dan Keadilan \\ p-ISSN 2302-7010 e-ISSN 2721-9801}

waktu, kewajiban bagi pegawai negeri mengikuti jam kerja sebagai pegawai negeri atau penyelenggara negara, sebagaimana ditentukan dalam peraturan perundang-undangan yang berlaku. Kedua, durasi waktu kewajiban bagi pegawai negeri atau penyelengagra negara itu melekat sampai ia pensiun atau sampai ia berhenti dari jabatannya sebagai pegawai negeri atau penyelenggara negara.

\section{Buku}

\section{DAFTAR PUSTAKA}

Baharuddin Lopa, 2000, Kejahatan Korupsi dan Penegakan Hukum, Cetakan Pertama,Jakarta: Kompas, 2000

Evi Hartanti, 2016, Tindak Pidana Korupsi, Edisi Revisi, Jakarta: Sinar Grafika, Cetakan Keenam.

Peter Mahmud Marzuki, 2010, Penelitian Hukum, Jakarta: Prenada Media Group. Ronny Hanitijo Soemitro, 1982, Metode Penelitian Hukum, Jakarta, Ghalia Indonesia.

\section{Peraturan Perundang-Undangan:}

Undang-Undang Dasar Negara Republik Indonesia Tahun 1945 (UUD NRI 1945). Undang-Undang Republik Indonesia Nomor 20 Tahun 2001 perubahan UndangUndang Nomor 31 Tahun 1999 tentang Pemberantasan Tindak Pidana Korupsi. Lembaran Negara Republik Indonesia Tahun 2001 Nomor 134.

Undang-Undang Nomor 5 Tahun 2014 tentang Aparatur Sipil Negara. Lembaran Negara Republik Indonesia Tahun 2014 Nomor 6.

Kitab Undang-Undang Hukum Pidana (KUHP)

Kitab Undang-Undang Hukum Perdata (KUHPerdata) 